\title{
PERANCANGAN SISTEM INFORMASI REGISTRASI IBADAH ONLINE BERBASIS QR-CODE MENGGUNAKAN FRAMEWORK LARAVEL
}

\author{
Irma Iswara Anatasia Komala Sari, Radius Tanone \\ Program Studi Teknik Informatika, Universitas Kristen Satya Wacana \\ J1. Diponegoro 52-60, Salatiga 50711, Indonesia \\ 672017167@student.uksw.edu, radius.tanone@uksw.edu
}

\begin{abstract}
Since Indonesia has experienced pandemic Covid-19 Virus, it has prolonged has forced every community to reduce physical contact with other people in order to minimize the spread of the Covid-19 Virus. Activities at companies, offices, UMKM, schools, universities, and wajid places of worship will be suspended until a specified time limit. Gradually, the development of the Covid-19 Virus has included a transition period, new normal. So the Indonesian government allows community activities to run normally again, including houses of worship. Not separated from Central Kalimantan Province, the City of Palangka Raya has begun to gradually open its doors to churches, especially the GKE Rajawali Church of the Asi Church, which regulates the capacity of congregants to worship offline not exceeding $50 \%$ and must comply with health protocols. Currently, the church is still registering worship through the application WhatsApp, but in this condition the church still has several obstacles that make worship registration ineffective. Thus, an information system was designed using $Q R$ Code as the main component that simplifies the registration process. QR Code is implemented on a-based information system web using the laravel framework developed using PHP and MySQL. The result of application testing uses two testing techniques bugs with the method black box and beta with quantitative methods. By Worship registration information system online QR-based Code using designing a laravel framework, it is hoped that the problems that have occurred before can be minimized properly.
\end{abstract}

Keywords - Covid-19 Virus, Laravel Framework, QR Code.

Abstrak - Penyebaran Virus Covid-19 di Indonesia dapat diminimalisir dengan memberikan penyuluhan rutin bahwa masyarakat harus mengurangi kontak fisik dengan orang lain selama pandemi ini berlangsung. Kegiatan pada perusahaan, perkantoran, UMKM, sekolah, universitas, maupun rumah ibadah wajid diberhentikan sampai batas waktu yang akan ditentukan. Lambat laun, perkembangan Virus Covid-19 telah memasukan masa transisi new normal. Maka pemerintah Indoensia memperbolehkan kegiatan masyarakat berjalan dengan normal kembali, termasuk rumah ibadah. Tidak lepas dari Provinsi Kalimantan Tengah, Kota Palangka Raya mulai bertahap membuka pintu gereja terkhususnya Majelis GKE Rajawali Gereja Asi yang mengatur kapasitas jemaat untuk beribadah secara offline tidak melebihi $50 \%$ dan wajib mematuhi protokol kesehatan. Saat ini, pihak gereja masih melakukan registrasi ibadah melalui aplikasi whatsapp, tetapi dalam kondisi tersebut pihak gereja masih memiliki beberapa kendala yang menjadikan registrasi ibadah menjadi tidak efektif. Maka, dirancanglah sistem informasi dengan memanfaatkan $Q R$ Code sebagai komponen utama yang mempermudah proses pendaftaran. MySQL dan PHP digunakan untuk mengembangkan framework laravel pada sistem informasi berbasis web melalui implementasi $Q R$ Code. Dengan metode kuantitatif, penulis telah menerapkan dua teknik pengujian bugs melalui metode beta dan black box. Dengan Perancangan sistem informasi registrasi ibadah online berbasis QR Code menggunakan framework latavel ini diharapkan kendala yang terjadi sebelumnya dapat diminimalisir dengan baik.

Kata Kunci - Virus Covid-19, Framework Laravel, QR Code.

\section{PENDAHULUAN}

Dalam berbagai aspek, terdapat banyak manfaat dalam menggunakan teknologi oleh masyarakat di era modern ini. Teknologi elektronik telah menunjang teknologi informasi dan komunikasi yang berkembang dengan cepat. Perkembangan ini terjadi dengan sangat cepat, masyarakat mengalami peningkatan teknologi dalam hitungan hari, menit, bahkan detik.
Di akhir tahun 2019, dunia mengalami serangan Virus Covid-19 yang dimana virus ini sangat berbahaya di negara-negara lain, dan juga di Indonesia. Pada saat munculnya virus Covid-19 pemerintah Indonesia sigap membuat sebuah peraturan baru yang salah satunya yaitu masyarakat Indonesia diwajibkan untuk menjaga jarak antar individu dengan individu lainnya minimal 1 meter dan masyarakat dipaksa untuk melakukan kegiatan di rumah saja secara daring, seperti beribadah, belajar, dan bekerja[1]. 
Seiring berjalannya waktu pada bulan mei 2020 perkembangan pandemi Covid-19 di Indonesia sudah memasuki masa transisi menuju tatanan kehidupan new normal, maka dari itu Menteri Agama mengatakan bahwa rumah ibadah dibuka secara bertahap dan beliau akan mengeluarkan Surat Edaran Panduan Penyelenggaraan Kegiatan Keagamaan di Rumah Ibadah. Tidak lepas dari Sekretaris Umum Persekutuan Gereja-gereja di Indonesia sudah mengeluarkan panduan protokol kesehatan Virus Covid-19 untuk umat Kristiani[2]. Selain mengatur persoalan menjaga jarak secara fisik, panduan tersebut juga melarang orang lanjut usia, penderita penjakit serius dan anak-anak untuk beribadah secara offline. Dikarenakan, orang lanjut usia, penderita penyakit serius dan anak-anak sangat rentan terkena Virus Covid-19[3].

Melihat perkembangan tersebut, beberapa Gereja di Kota Palangka Raya, Kalimantan Tengah mulai bertahap membuka pintu Gereja yang mana pihak Gereja mengatur kapasitas kuota jemaat untuk beribadah di Gereja tidak melebihi dari $50 \%$ dan harus mematuhi protokol kesehatan[4]. Setelah mengetahui peraturan yang berlaku, pihak Geraja membuat peraturan yang salah satunya adalah pembatasan kuota jemaat. Di dalam aturan tersebut pihak Gereja menyatakan bahwa pada saat jadwal ibadah subuh hanya menerima kuota jemaat maksimal 100 orang termasuk petugas ibadah, ibadah pagi hanya menerima maksimal 50 orang termasuk petugas ibadah dan ibadah sore maksimal 50 orang termasuk petugas ibadah. Saat ini, pihak gereja masih menggunakan aplikasi pengirim pesan seperti aplikasi whatsapp yang mana jemaat harus melakukan pendaftaran dengan mencantumkan data dirinya sendiri ataupun data anggota keluarga yang ingin datang beribadah. Permasalahan yang dialami pihak Gereja sangatlah tidak efektif, dikarenakan jemaat yang melakukan pendaftaran tersebut hanya mencantumkan satu data dirinya saja, sedangkan ketika jemaat tersebut datang beribadah tidak dipungkiri bahwa jemaat tersebut membawa beberapa anggota keluarganya yang tidak dicantumkan pada pendaftaran yang sudah dilakukan sebelumnya. Maka dari itu, jemaat yang tidak mencantumkan data anggota keluarganya yang ingin beribadah dipersilahkan kembali kerumah masingmasing dan disarankan agar mengikuti ibadah online saja. Pihak Gereja dan jemaat wajib mematuhi peraturan yang sudah diatur oleh pemerintah dan pihak Gereja. Sistem yang digunakan ini masih sangat kurang efektif, karena selalu mengakibatkan miss coommunication terhadap pihak Gereja dan Jemaat

Penulis telah merumuskan masalah berdasarkan uraian di atas yaitu bagimana membuat sistem informasi registrasi ibadah online berbasis $Q R$ Code menggunakan framework laravel yang dapat mengelola data informasi registrasi ibadah online, bagaimana generete $Q R$ Code agar terdapat data registrasi jemaat di dalamnya, dan penerapan framework laravel untuk membuat sebuah aplikasi perancangan sistem menjadi berbasis web.

Adapun tujuan penelitian sistem ini adalah memberikan pemecahan masalah kepada pihak gereja dengan menggunakan sistem informasi registrasi berbasis $Q R$ Code menggunakan framework laravel. Sedangkan manfaat yang didapat adalah data informasi jemaat yang ingin melakukan ibadah offline di Gereja dapat terbaca dengan cepat dan akurat, dan memudahkan pihak Gereja menginformasikan peraturan protokol kesehatan dan membatasi kapasistas yang akan beribada secara offline di Gereja.

Agar tidak terjadinya duplikasi, penelitian ini akan dilakuka penelusuran untuk membandingkan antara penelitian yang telah dilakukan oleh pihak yang lain. Peneliti telah melakukan riset beberapa literature review yang telah dilakukan sebelumnya yaitu:

Pertama, sebuah studi yang berjudul "Sistem Manajemen Arsip menggunakan Framework Laravel dan Vue.js (Studi Kasus : BPKAD Provinsi Bali). Studi ini dilakukan oleh Putra, Pramana, dan Srinadi pada tahun 2019. Di Provinsi Bali, terdapat 25.000 SP2D yang dikeluarkan untuk dikelola oleh badan keuangan daerah selama satu tahun. Sehingga peneliti hendak membantu mengurangi beban kinerja pegawai BPKAD Prov Bali. Penyusunan arsip dilakukan sesuai dengan jangka waktu yang sudah ditentukan dan usia hidup berdasarkan permintaan kebutuhan dalam pemeriksaan dan pemeliharaan arsip. Letak penyimpanan arsip tidak bisa diakses dengan cepat karena tidak adanya sumber informasi mengenai hal tersebut. Hal ini terjadi karena masih manualnya aktivitas mencatat, menyimpan, dan mencairkan arsip. Sehingga proses manual dalam pencairan arisp semakin sulit dilakukan kerena peningkatan jumlah arsip yang dimiliki. Melihat permasalahan tersebut penulis pun membuat sistem yang terkait dengan masalah yang ada. Penulis membuat sistem ini menggunakan framework laravel dan Vue.js dengan menggunakan fitur $Q R$ Code. Karyawan tidak harus mencari satu persatu dokumen yang hendak dicari karena mereka dapat mengidentifikasi lokasi penyimpanan arsipi melalui $Q R$ Code [5].

Penelitian yang dilakukan oleh Zen Munawar, ST, S.Kom (2019) dengan judul "Aplikasi Registrasi Seminar Berbasis Web menggunakan $Q R$ Code Pada Universitas XYZ". Pada penelitian ini penulis bertujuan untuk mempermudah universitas dalam melaksanakan kegiatan seminar yang selama ini peserta harus melakukan registrasi terlebih dahulu yang tiketnya masih menggunakan dalam bentuk kertas yang biasanya disebut dengan registrasi konvensional. Permasalahan yang timbul dari registrasi konvensional dalam seminar tersebut yaitu tidak efisiensinya waktu, karena mengharuskan peserta untuk datang ke suatu tempat yang telah ditentukan untuk melakukan registrasi seminar. Penulis menggunakan sistem registrasi berbasis $Q R$ Code yang mana informasi diakses dengan menangkap sebuah 
kode dalam bentuk foto dengan menggunakan kamera dan menangani kode tersebut dengan pembaca $Q R$. Melihat dari masalah tersebut penulis mengharapkan aplikasi yang dirancang dapat digunakan sebagaimana salah satu alat yang dapat mempermudah panitia dan peserta seminar untuk menghadiri acara seminar tersebut[6].

Taylor Otwell merancang sebuah framework open source PHP berbasis web gratis yang dikenal dengan laravel yang digunakan dalam studi ini. Pola arsitektur atau model-view-controller (MVC) merupakan referensi pengembangan aplikasi web tersebut. Laravel memiliki beberapa fitur menarik seperti tool yang dapat memelihara dengan mudah dan membantu penyebaran aplikasi, menjelaskan proses yang berebeda dalam akses database relasional, dan mengembangkan sistem modul yang mampu dikelola dengan sederhana [7].

Dapat melakukan pembaharuan, melakukan sisipan, mengaplikasikan klausula untuk menyaring baris, mengambil baris dengan keyword utama, melakukan interaksi pada database seperti mengambil semua baris merupakan beberapa fungsi yang dapat dilakukan di framework laravel. Seseorang dapat dengan mudah merancang sebuah sistem berbasis web sesuai dengan kebutuhan. Laravel bersama dengan Yii2, CodeIgniter, Nette, dan Symfony2 telah menjadi kerangka kerja PHP yang paling digemari sejak maret 2015 [8].

\section{METODE PENELITIAN}

Peneliti memiliki 10 tahap penelitian dalam studi ini yaitu:

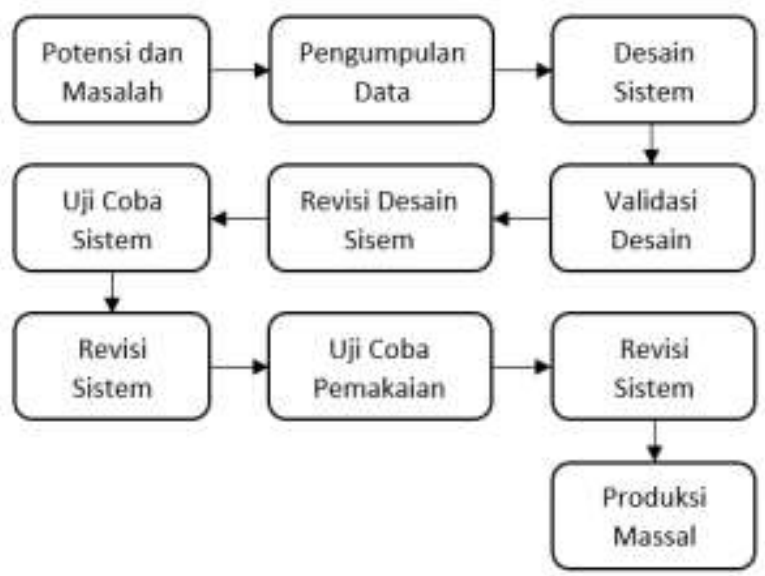

Gambar 1. Tahap Penelitian Metode R\&D[9]

Melalui gambar di atas, peneliti akan menjelaskan setiap tahap yang ada yaitu:

1. Potensi dan masalah

Data potensi dan masalah didapat dari wawancara kepada pihak Gereja yang mengalami prosedur pendaftaran ibadah yang masih menggunakan aplikasi pengirim pesan seperti aplikasi whatsapp yang sangat kurang efektif.
2. Pengumpulan Data

Akan dilakukan wawancara kepada pihak Geraja yang sedang bertugas maupun mewawancarai kepada salah satu jemaat Geraja. Sebagai bahan untuk perencanaan, informasi akan digunakan setelah peneliti memperoleh data yang diinginkan.

3. Desain Sistem

Setelah mengetahui potensi, masalah dan pengumpulan data yang terjadi di lapangan, maka tahap selanjutnya melakukan desain sistem awal yang mana akan desain sistem ini akan digunakan dalam perancangan sistem baru.

4. Validasi Desain

Pada langkah ini, seseorang yang ahli akan menilai apakah rancangan desain memiliki sistem yang efektif dan lebih baik dari sebelumnya.

5. Revisi Desain Sistem

Peneliti akan melakukan revisi setelah mengetahui kelemahan berdasarkan penilaian ahli yang sudah berpengalaman.

6. Uji Coba Sistem

Selanjutnya, peneliti akan melakukan uji coba sistem yang telah dirancang sebelumnya sehingga dapat memperoleh informasi tentang apakah terdapat bugs dalam sistem tersebut.

7. Revisi Sistem

Pada tahap ini, akan dilakukan penambahan halhal yang kurang pada sistem yang dibuat berdasarkan uji coba yang terbatas.

8. Uji Coba Pemakaian

Selanjutnya, peneliti akan mengadakan uji coba penggunaaan untuk mengetahui apakah sistem yang dirancang sudah layak atau belum.

9. Revisi Sistem

Apabila pada saat uji coba sesungguhnya terdapat kekurangan dalam penggunaan, maka sistem yang dihasilakan akan direvisi kembali.

10. Produksi Massal

Selanjutnya, akan dilakukan produksi secara terbatas sesuai kepentingan penelitian[9].

Sebelum masuk kedalam penjelasan, sebelumnya akan membahas tentang Framework Laravel dan $Q R$ Code. Framework Laravel memiliki 3 struktur bagian yang terdiri antara model, view, dan controller (MVC). Sebuah aplikasi memiliki inti dan logika bisnis yang disebut modul (Model). Pengguna dapat merespon interface yang terdapat dalam sistem yang dikenal dengan "View". Sedangkan kombinasi dalam pengimplementasikan model dan view dapat dilakukan dengan "Controller" [10].

Terdapat pemisahan ketiga komponen penting dalam MVC yaitu komponen kontrol (controller), komponen desain (view), dan komponen data (model) dalam paradigma pengambangan sistem. Setiap komponen saling berhubungan meskipun komponen tersebut dapat berdiri sendiri. 
Software yang lebih efisien dapat dihasilkan oleh arsitektur MVC. Sehingga pengembangan software dapat lebih mudah dilakukan dalam mengelola informasi registrasi yang digunakan oleh user ketika menggunakan software tersebut.

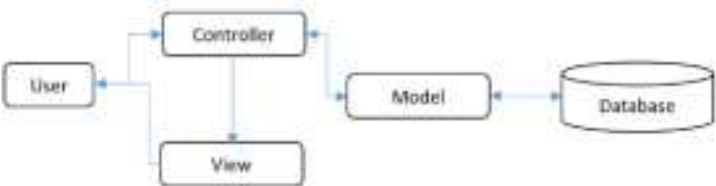

Gambar 2. Alur Konsep Model-View-Controller (MVC)

Pada Gambar 9 menggambarkan pengelolaan database oleh MVC berdasarkan kerangka kerja PHP [11].

Suatu media yang lebih ringkas dapat dicetak dan diakses oleh kode dua dimensi yang terdapat dalam QR Code. Pada tahun 1994, perusahaan Jepang DensoWave memperkenalkan pertama kali barcode dua dimensi atau $Q R$ Code. Meskipun saat ini telah diterapkan dalam banyak bidang, awalnya pendataan inventaris produksi suku cadang kendaraan merupakan pengguna barcode ini untuk pertama kali. Penerjemahan dengan cepat merupakan konsep awal dari sistem Quick Response atau $Q R$ dalam sistem barcode tersebut. Barcode satu dimensi adalah referensi dari $Q R$ Code. Saat ini kamera smartphone dapat membaca barcode yang dikenal dengan $Q R$ Code dengan mudah [12].

Data kanji/kana, hangul, biner, arab, bugsnumeric, dan angka/numeric merupakan jenis data yang dapat disimpan oleh $Q R$ Code. Dibandingkan dengan barcode, tampilan yang lebih kecil dapat dimiliki oleh $Q R$ Code. Ukuran $Q R$ Code hanya 1/10 dari barcode biasa karena dapat menyimpan data secara vertikal dan horizontal, Tahan pada kerusakan merupakan keuntungan lain dari $Q R$ Code. Ukuran atau versi dapat mempengaruhi kemampuan dalam memperbaiki kesalahan sebesar 30 persen pada $Q R$ Code. Sehingga pengguna dapat membaca dan menyimpan data meskipun simbol $Q R$ Code telah rusak atau kotor. Pengguna dapat membaca hasil dari sudut manapun dan memperoleh hasil yang sama berdasarkan 3 tanda berbentuk persegi di 3 sudut [13].

Terdapat Versi 1 sampai Versi 40 terhadap simbol $Q R$ Code. Jumlah modul atau konfigurasi modul akan mempengaruhi setiap versi. $Q R$ Code terbentuk dari titik-titik putih dan hitam pada tiap modul. Sebuah simbol memiliki jumlah modul tertentu berdasarkan "Konfigurasi Modul". Versi 1 adalah 21x21 modul sedangkan Versi 40 adalah 177x177 modul. Terdapat 4 modul tambahan persamping pada setiap nomor versi yang lebih tinggi.

Terdapat tingkat kesalahan koreksi, jenis karakter, dan jumlah data yang sesuai dengan kapasitas data pada setiap versi simbol $Q R$ Code. Pada setiap versi dapat menentukan kapasitas maksimum untuk memeriksa data yang diperlukan. Simbol $Q R$ Code akan semakin besar jika jumlah modul dan data semakin tinggi untuk versi dan kapasitas data maksimum [13].

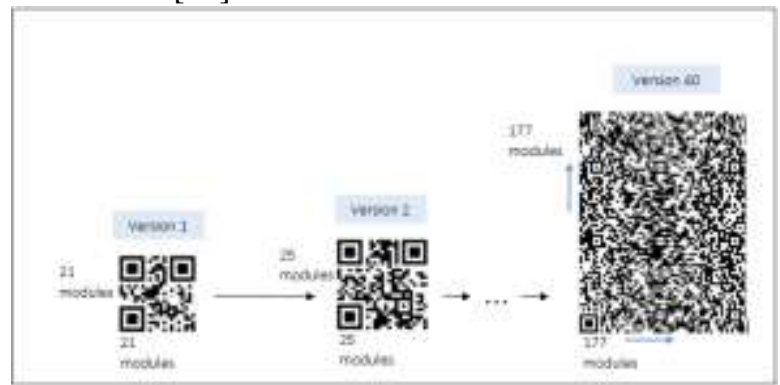

Gambar 3. QR Code Symbol Version

Jika kode rusak atau kotor, data dapat dikembalikan atau dikoreksi berdasarkan kemampuan $Q R$ Code. $Q R$ Code mampu memeriksa kesalahan berdasarkan 4 tingkatan kesalahan pemeriksaan yang dapat dimanfaatkan pengguna. Pengguna dapat mengetahui tingkat kesalahan dengan mempertimbangkan ukuran dan faktor lingkungan pada $Q R$ Code. $Q R$ Code akan mengalami kerusakan jika kondisi lingkungan kotor dan pengguna dapat memilih tingkat $\mathrm{Q}$ dan $\mathrm{H}$. Jika kondisi memiliki lingkungan bersih dan jumlah data yang dimiliki besar, pengguna dapat memilih tingkat L. Sedangkan yang paling sering digunakan oleh pengguna adalah tingkat M. QR Code memiliki panduan pemeriksaan kesalahan yaitu [13].

Tabel 1. Koreksi Kesalahan Pada $Q R$ Code Kapasitas Koreksi Kesalahan QR Code

\begin{tabular}{|l|l|}
\hline Level H & $\begin{array}{l}\text { Mampu mengoreksi keselahan sampai } \\
30 \%\end{array}$ \\
\hline Level Q & $\begin{array}{l}\text { Mampu mengoreksi keselahan sampai } \\
25 \%\end{array}$ \\
\hline Level M & $\begin{array}{l}\text { Mampu mengoreksi keselahan sampai } \\
15 \%\end{array}$ \\
\hline Level L & $\begin{array}{l}\text { Mampu mengoreksi keselahan sampai } \\
7 \%\end{array}$ \\
\hline
\end{tabular}

\section{HASIL DAN PEMBAHASAN}

Peneliti akan membahas desain dari sistem yang akan dibuat berdasarkan uraian yang telah dijelaskan pada metode penelitian.

A. Perancangan Sistem Dengan Unified Modeling Language (UML)

UML akan digunakan dengan logic model sebagai bentuk yang akan ditampilkan dan dibangun dalam proses perancangan. UML akan digunakan dalam perancangan berikut ini.

B. Use Case Diagram Sistem

Pengguna dapat mengetahui aplikasi apa yang sedang dibuat berdasarkan fungsionalitas dari suatu sistem pada use case diagram [14]. Pada sistem informasi registrasi ibadah online ini memiliki 2 actor yaitu Admin Gereja dan Majelis 
Jemaat. Admin Gereja atau administrator dapat mengelola batasan kuota, mengelola data informasi, melihat data jemaat registrasi ibadah, melakukan scanner terhadap $Q R$ Code, dan mengunduh data registrasi jemaat dengan melakukan proses login terlebih dahulu. Sedangkan majelis jemaat dapat melakukan registrasi ibadah, menampilkan $Q R$ Code, melihat informasi, dan melihat kontak dengan proses login yang sebelumnya sudah melakukan pendaftaran akun terlebih dahulu. Dapat dilihat pada gambar di bawah ini.

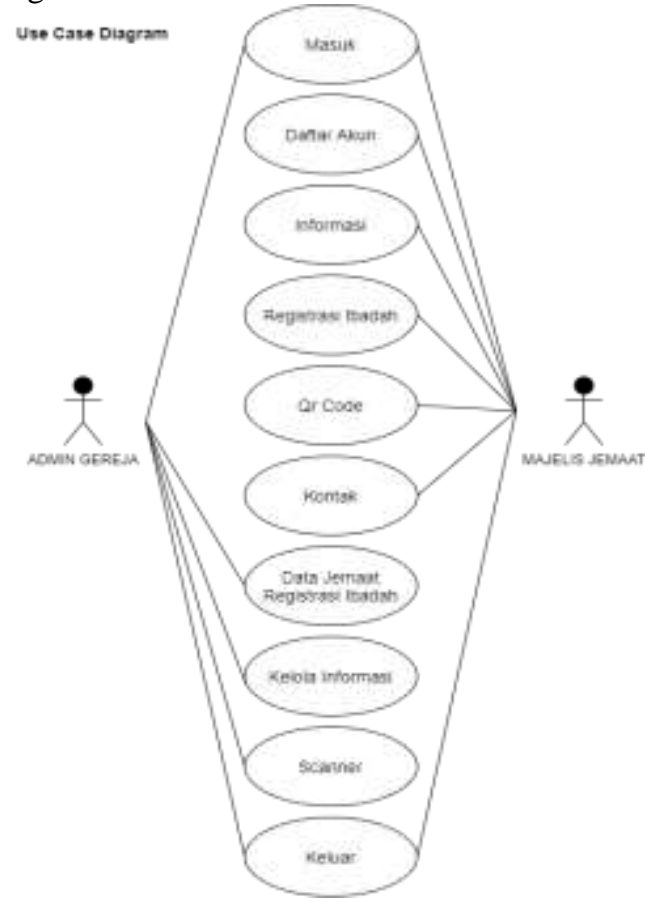

Gambar 2. Use Case Diagram Sistem

\section{Penjabaran Use Case Diagram Admin Gereja}

Penjabaran use case diagram untuk aplikasi registrasi ibadah online ini didefinisikan atas definisi aktor. Aktor admin Gereja merupakan aktor yang memiliki hak akses secara keseluruhan yang dapat melakukan akses seperti fitur scanner, data registrasi ibadah, dan kelola informasi. Gambar di bawah merupakan penjabaran $U C D$.

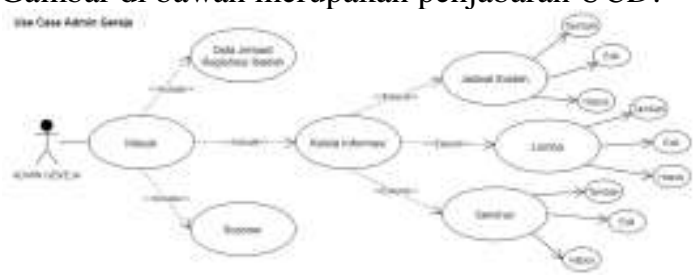

Gambar 3. Penjabaran Use Case Diagram Admin Gereja

\section{Penjabaran Use Case Diagram Majelis Jemaat}

Penjabaran use case diagram untuk aplikasi registrasi online ini didefinisikan atas definisi aktor. Aktor majelis gereja merupakan aktor yang memiliki hak akses secara keseluruhan yang dapat melakukan akses seperti fitur informasi, registrasi ibadah, $Q R$ Code, dan kontak.

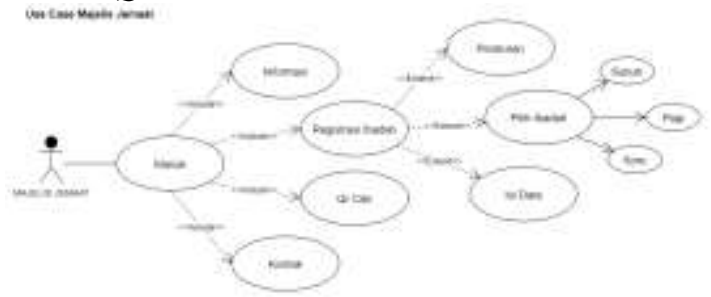

Gambar 4. Penjabaran Use Case Diagram Majelis Jemaat

\section{E. Activity Diagram}

Pada activity diagram menunjukkan bahwa sebuah aktifitas pengguna saat akan masuk kesebuah sistem dengan aplikasi dan melakukan pengisian email dan password kemudian sistem akan melakukan validasi benar atau salah. Jika salah maka sistem menampilkan pesan gagal login pada tampilan form login, namun jika login yang dilakukan benar maka sistem akan menampilkan halam utama. Kemudian pengguna akan masuk pada halaman utama aplikasi.

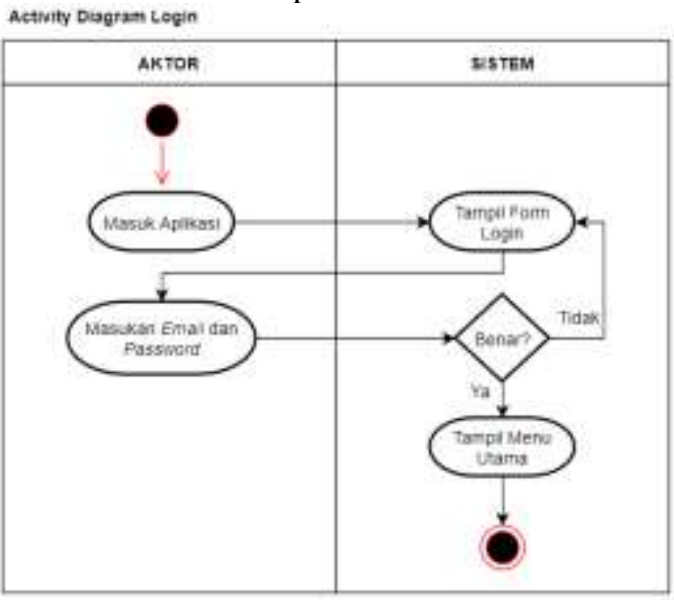

Gambar 5. Activity Diagram Login

\section{F. Rancangan Interface}

Terdapat 8 tahapan desain interface pada studi ini seperti:

1. Interface Login

Di tahap ini pengguna dapat masuk ke halaman utama registrasi ibadah online. Gambar 6 di bawah ini merupakan interface login.

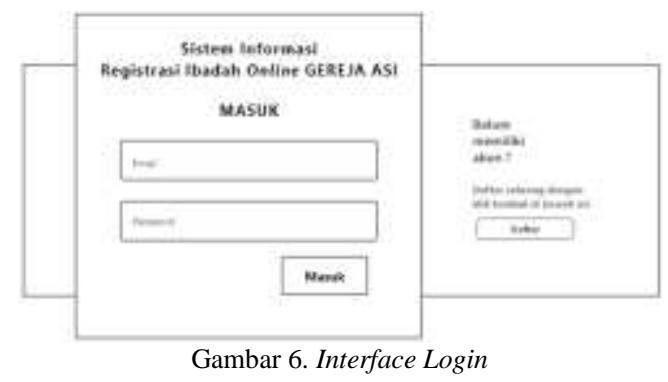


2. Interface Informasi Pengguna

Fitur ini berfungsi agar pengguna aplikasi dapat lebih mudah mengetahui informasi jadwal ibadah, lomba, dan seminar yang berhubungan dengan Majelis GKE Rajawali Gereja Asi. Gambar 7 di bawah ini merupakan interface informasi pengguna.

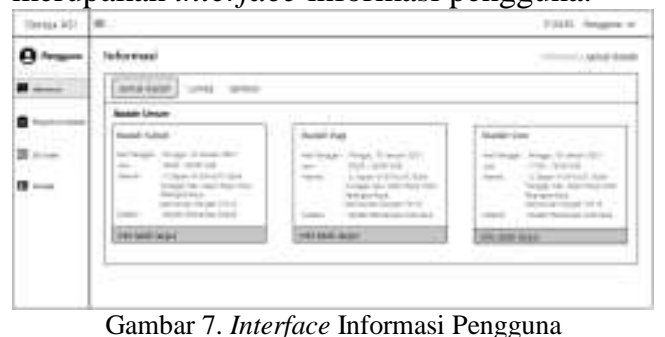

3. Interface Regristrasi Ibadah Pengguna

Pada bagian ini pengguna dapat melakukan registrasi ibadah yang di dalamnya terdapat peraturan selama mengikuti ibadah offline, memilih jadwal ibadah, dan mengisi data pengguna untuk persyaratan registrasi ulang di Gereja. Gambar 8 di bawah ini merupakan interface Registrasi Ibadah Pengguna.

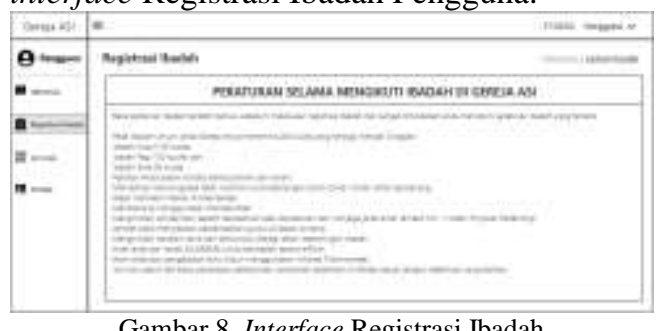

Gambar 8. Interface Registrasi Ibadah

4. Interface $Q R$ Code Pengguna

Pengguna yang sudah melakukan registrasi ibadah sebelumnya dapat melihat informasi data berdasarkan $Q R$ Code yang digunakan dalam tahapan ini. Pada bagian ini pengguna dapat mengunduh $Q R$ Code. Gambar 9 di bawah ini merupakan interface $Q R$ Code pengguna

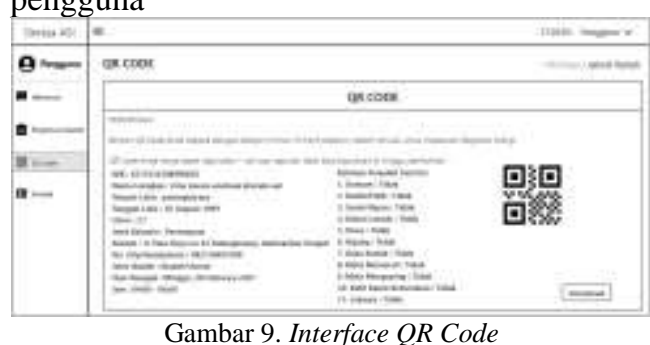

5. Interface Kontak Pengguna

Pada interface ini digunakan untuk menampilkan informasi kontak kantor pusat dan media sosial Majelis GKE Rajawali Gereja Asi Palangka Raya. Gambar 10 di bawah ini merupakan interface kontak pengguna.

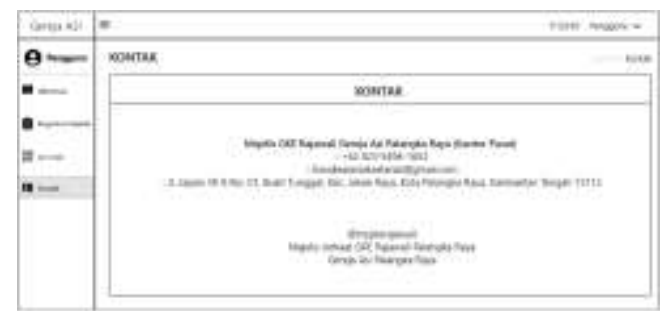

Gambar 10. Interface Kontak Pengguna

6. Interface Data Registrasi Ibadah Admin Pada interface ini digunakan agar admin bisa melihat data-data jemaat yang sudah melakukan registrasi ibadah. Gambar 11 di bawah ini merupakan interface data registrasi ibadah admin.

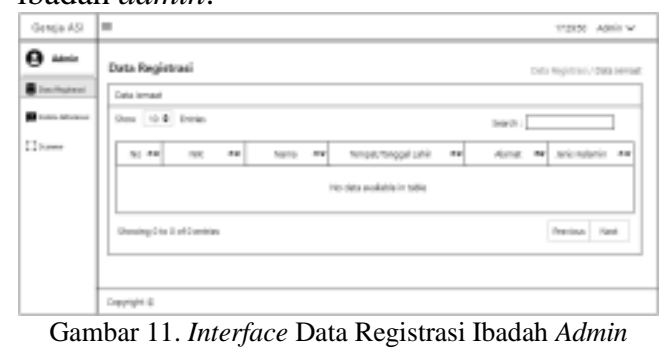

7. Interface Kelola Informasi Admin

Pada bagian ini admin dapat melihat, menambah, ubah, dan hapus informasi terkait jadwal ibadah, lomba dan seminar. Gambar 12 di bawah ini merupakan interface kelola Informasi admin.

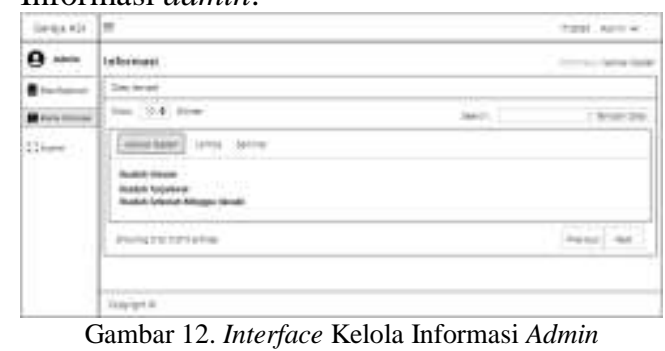

8. Interface Scanner Admin

QR Code jemaat akan discan oleh admin pada interface ini. Camera yang digunakan pada sistem ini sudah otomatis terhubung dengan webcam. Setelah dilakukan scanner maka sistem akan menampilkan perintah apakah admin ingin mengunduh dokumen $P D F$ yang mana dokumen tersebut merupakan data registrasi ibadah jemaat. Gambar 13 di bawah ini merupakan interface scanner admin.

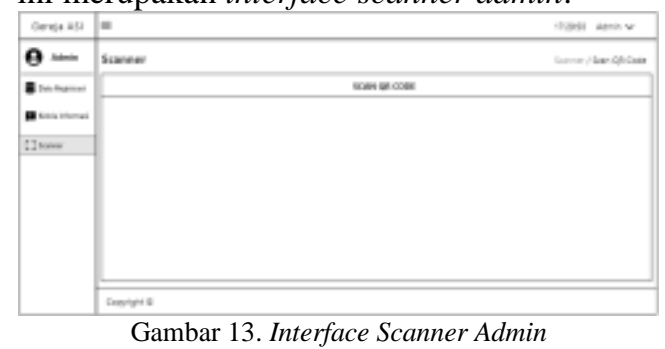




\section{G. Implementasi Sistem}

Implementasi user dan implementasi admin terdapat dalam implementasi sistem aplikasi.

1. Form Login Pada Implementasi Admin Dan Pengguna

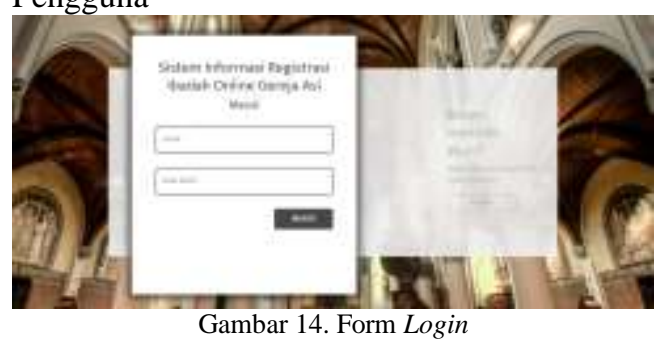

Pengguna dapat melakukan autentikasi pada dua textbok yang ada pada form login. Free text merupakan isian yang dapat dientri dalam form email dan password ketika akan masuk dalam aplikasi.

2. Form Informasi Pada Implementasi Pengguna

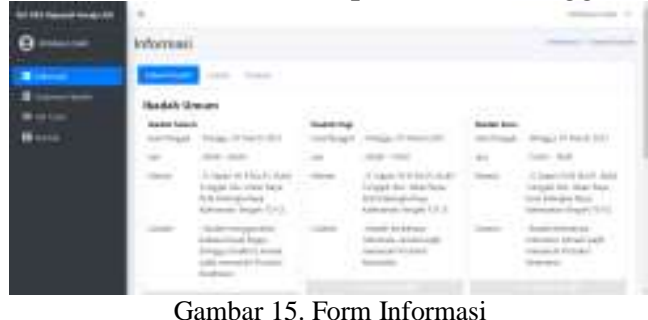

Form informasi menyajikan tombol pada box informasi yang mana pengguna akan langsung menuju menu registrasi ibadah agar dapat mengetahui informasi lebih seperti peraturan selama mengikuti ibadah di Gereja. Pada form informasi ini terdapat menu jadwal ibadah, lomba, dan seminar.

3. Form Registrasi Ibadah Pada Implentasi Pengguna

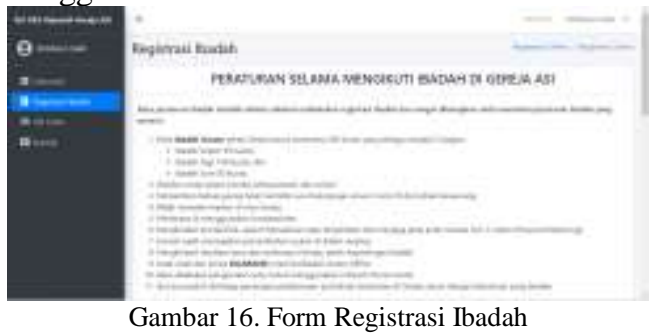

Form registrasi ibadah menyajikan kepada pengguna melakukan registrasi ibadah. Pada form ini pengguna dapat melihat peraturan selama mengikuti ibadah, jika scrolling ke bawah maka pengguna dapat memilih ibadah umum yang mencakup ibadah subuh, pagi, dan sore dengan kuota yang terbatas. Dan selanjutnya pengguna akan mengisi data diri untuk melakukan registrasi ibadah lebih lanjut.
4. Form $Q R$ Code pada implementasi Pengguna

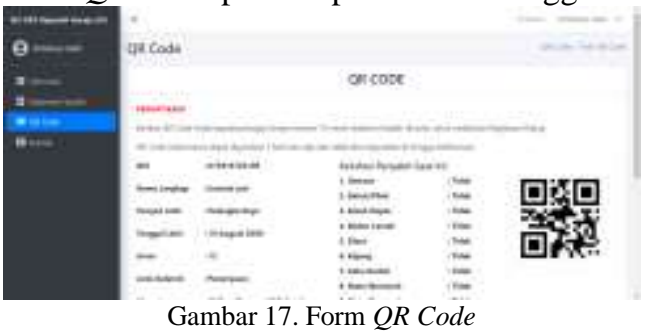

Pada form ini dapat diliat bahwa data-data pengguna yang sudah melakukan registrasi ibadah akan terlihat dan akan otomatis masuk ke dalam $Q R$ Code.

5. Form Kontak Pada Implementasi Pengguna

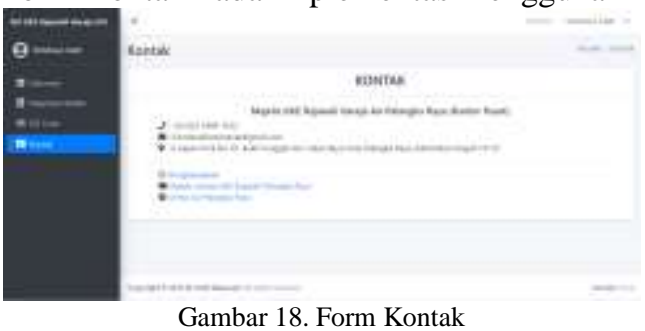

Form kontak berisikan nomor telepone kantor pusat, email, alamat, dan media sosial yang dimiliki oleh Majelis GKE Rajawali Gereja Asi.

6. Form Data Registrasi Ibadah Pada Implementasi Admin

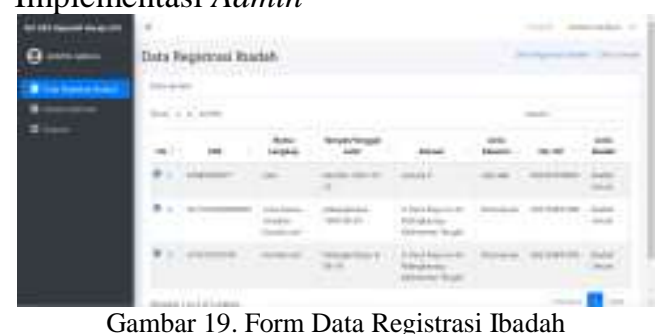

Form ini berisikan tabel data pengguna yang telah melakukan registrasi ibadah. Form ini juga menyajikan adanya search box agar admin dapat mudah mencari nama pengguna.

7. Form Kelola Informasi Pada Implementasi Admin

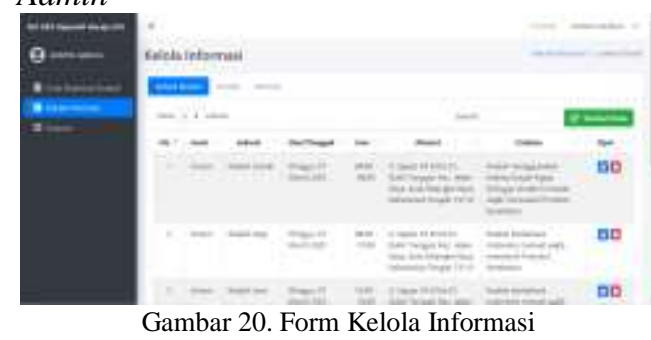

Pengguna dapat mencari informasi pada kolom search box. Sedangkan untuk menambah informasi, pengguna dapat 
menekan tombol kelola informasi. Pada menu tersebut digunakan untuk menampilkan seluruh jadwal ibadah yang telah dibuat sebelumnya oleh admin. Form ini memiliki tiga menu informasi yaitu jadwal ibadah, lomba dan seminar. Pada setiap record tersedia tombol option untuk mengubah, dan menghapus record.

8. Form Scanner pada implementasi admin

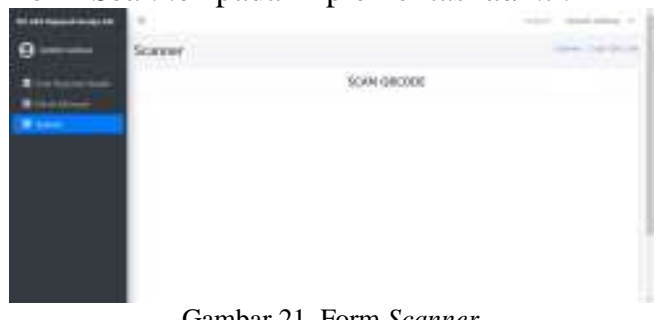

Gambar 21. Form Scanner

Form ini digunakan admin untuk melakukan scan terhadap $Q R$ Code yang dimiliki pengguna. Setelah dilakukan scanner maka sistem akan menampilkan perintah apakah admin ingin mengunduh dokumen $P D F$ yang mana dokumen tersebut merupakan data registrasi ibadah jemaat.

\section{H. Pengujian}

Peneliti telah memeriksa apakah terdapat bugs atau kesalahan pada sistem dengan menguji fungsi dan fitur dalam aplikasi yang telah dibangun. Kebutuhan pengguna diharapkan dapat terpenuhi dan berjalan sesuai dengan rencana saat melakukan pengujian sistem ini. Peneliti menerapkan metode kuantitatif dengan menguji bugs melalui metode beta dan blackbox dalam pengujian aplikasi ini.

1. Metode blackbox digunakan dalam pengujian teknik bugs.

Tabel 1. Pengujian Bugs Dengan Metode Black Box

\begin{tabular}{|c|c|c|c|c|}
\hline $\begin{array}{c}\text { Fungsi } \\
\text { yang } \\
\text { diuji }\end{array}$ & Kondisi & $\begin{array}{c}\text { Output } \\
\text { yang } \\
\text { diharap } \\
\text { kan }\end{array}$ & $\begin{array}{c}\text { Output } \\
\text { yang } \\
\text { dihasil } \\
\text { kan }\end{array}$ & Status \\
\hline \multirow[t]{2}{*}{ Login } & $\begin{array}{l}\text { Email } \\
\text { dan } \\
\text { password } \\
\text { benar }\end{array}$ & $\begin{array}{l}\text { Sukses } \\
\text { login dan } \\
\text { menampi } \\
\text { lkan } \\
\text { pesan } \\
\text { "Anda } \\
\text { berhasil } \\
\text { masuk" }\end{array}$ & $\begin{array}{l}\text { Sukses } \\
\text { login dan } \\
\text { menampi } \\
\text { lkan } \\
\text { pesan } \\
\text { "Anda } \\
\text { berhasil } \\
\text { masuk" }\end{array}$ & \multirow[t]{2}{*}{ Valid } \\
\hline & $\begin{array}{l}\text { Email } \\
\text { dan } \\
\text { password } \\
\text { salah }\end{array}$ & $\begin{array}{l}\text { Gagal } \\
\text { login dan } \\
\text { menampi } \\
\text { lkan } \\
\text { pesan } \\
\text { "Email } \\
\text { atay } \\
\text { password } \\
\text { salah" }\end{array}$ & $\begin{array}{l}\text { Gagal } \\
\text { login dan } \\
\text { menampi } \\
\text { lkan } \\
\text { pesan } \\
\text { "Email } \\
\text { atay } \\
\text { password } \\
\text { salah" }\end{array}$ & \\
\hline
\end{tabular}

\begin{tabular}{|c|c|c|c|c|}
\hline $\begin{array}{c}\text { Fungsi } \\
\text { yang } \\
\text { diuji }\end{array}$ & Kondisi & $\begin{array}{c}\text { Output } \\
\text { yang } \\
\text { diharap } \\
\text { kan }\end{array}$ & $\begin{array}{c}\text { Output } \\
\text { yang } \\
\text { dihasil } \\
\text { kan }\end{array}$ & Status \\
\hline Register & $\begin{array}{l}\text { Nama, } \\
\text { email, } \\
\text { password } \\
\text { confirmat } \\
\text { ions } \\
\text { password }\end{array}$ & $\begin{array}{l}\text { Sukses } \\
\text { register } \\
\text { dan } \\
\text { menampi } \\
\text { lkan } \\
\text { pesan } \\
\text { "Akun } \\
\text { anda } \\
\text { berhasil } \\
\text { dibuat" }\end{array}$ & $\begin{array}{l}\text { Sukses } \\
\text { register } \\
\text { dan } \\
\text { menampi } \\
\text { lkan } \\
\text { pesan } \\
\text { "Akun } \\
\text { anda } \\
\text { berhasil } \\
\text { dibuat" }\end{array}$ & Valid \\
\hline $\begin{array}{l}\text { Load } \\
\text { Data } \\
\text { Registras } \\
\text { i }\end{array}$ & $\begin{array}{l}\text { Buka } \\
\text { halaman } \\
\text { registrasi } \\
\text { ibadah }\end{array}$ & $\begin{array}{l}\text { Menampi } \\
\text { lkan data } \\
\text { registrasi } \\
\text { ibadah } \\
\text { jemaat }\end{array}$ & $\begin{array}{l}\text { Menampi } \\
\text { lkan data } \\
\text { registrasi } \\
\text { ibadah } \\
\text { jemaat }\end{array}$ & Valid \\
\hline \multirow[t]{2}{*}{$\begin{array}{l}\text { Tambah } \\
\text { Data } \\
\text { Informasi }\end{array}$} & $\begin{array}{l}\text { Form } \\
\text { diisi } \\
\text { dengan } \\
\text { benar }\end{array}$ & $\begin{array}{l}\text { Sukses } \\
\text { tambah } \\
\text { data dan } \\
\text { menampi } \\
\text { lkan } \\
\text { pesan } \\
\text { "Data } \\
\text { berhasil } \\
\text { ditambah } \\
\text { " }\end{array}$ & $\begin{array}{l}\text { Sukses } \\
\text { tambah } \\
\text { data dan } \\
\text { menampi } \\
\text { lkan } \\
\text { pesan } \\
\text { "Data } \\
\text { berhasil } \\
\text { ditambah } \\
\text { " }\end{array}$ & \multirow[t]{2}{*}{ Valid } \\
\hline & $\begin{array}{l}\text { Form } \\
\text { diisi } \\
\text { beberapa } \\
\text { atau } \\
\text { salah }\end{array}$ & $\begin{array}{l}\text { Menampi } \\
\text { lkan } \\
\text { pesan } \\
\text { "Please } \\
\text { select an } \\
\text { item in } \\
\text { the list"" }\end{array}$ & $\begin{array}{l}\text { Menampi } \\
\text { lkan } \\
\text { pesan } \\
\text { "Please } \\
\text { select an } \\
\text { item in } \\
\text { the list"" }\end{array}$ & \\
\hline $\begin{array}{l}\text { Ubah } \\
\text { Data } \\
\text { Informasi }\end{array}$ & $\begin{array}{l}\text { Form } \\
\text { diisi } \\
\text { dengan } \\
\text { benar }\end{array}$ & $\begin{array}{l}\text { Sukses } \\
\text { ubah data } \\
\text { dan } \\
\text { menampi } \\
\text { lkan } \\
\text { pesan } \\
\text { "Data } \\
\text { berhasil } \\
\text { diubah" } \\
\end{array}$ & $\begin{array}{l}\text { Sukses } \\
\text { ubah data } \\
\text { dan } \\
\text { menampi } \\
\text { lkan } \\
\text { pesan } \\
\text { "Data } \\
\text { berhasil } \\
\text { diubah" }\end{array}$ & Valid \\
\hline $\begin{array}{l}\text { Hapus } \\
\text { Data } \\
\text { Informasi }\end{array}$ & $\begin{array}{l}\text { Pilih } \\
\text { salah satu } \\
\text { data }\end{array}$ & $\begin{array}{l}\text { Sukses } \\
\text { hapus } \\
\text { data dan } \\
\text { menampi } \\
\text { lkan } \\
\text { pesan } \\
\text { "Data } \\
\text { berhasil } \\
\text { dihapus" }\end{array}$ & $\begin{array}{l}\text { Sukses } \\
\text { hapus } \\
\text { data dan } \\
\text { menampi } \\
\text { lkan } \\
\text { pesan } \\
\text { "Data } \\
\text { berhasil } \\
\text { dihapus" }\end{array}$ & Valid \\
\hline \multirow[t]{2}{*}{$\begin{array}{l}\text { Load } \\
\text { Scanner }\end{array}$} & $\begin{array}{l}\text { QR Code } \\
\text { berlaku }\end{array}$ & $\begin{array}{l}\text { Menampi } \\
\text { lkan } \\
\text { document } \\
\text { PDF data } \\
\text { registrasi } \\
\text { ibadah } \\
\text { jemaat } \\
\text { dan } \\
\text { button } \\
\text { download }\end{array}$ & $\begin{array}{l}\text { Menampi } \\
\text { lkan } \\
\text { document } \\
\text { PDF data } \\
\text { registrasi } \\
\text { ibadah } \\
\text { jemaat } \\
\text { dan } \\
\text { button } \\
\text { download }\end{array}$ & \multirow[t]{2}{*}{ Valid } \\
\hline & $\begin{array}{l}Q R \text { Code } \\
\text { tidak } \\
\text { berlaku }\end{array}$ & $\begin{array}{l}\text { Manampi } \\
\text { lkan } \\
\text { pesan } \\
\text { "Scanner } \\
\text { gagal, } \\
\text { QR Code } \\
\text { sudah } \\
\text { terpakai" }\end{array}$ & $\begin{array}{l}\text { Manampi } \\
\text { lkan } \\
\text { pesan } \\
\text { "Scanner } \\
\text { gagal, } \\
\text { QR Code } \\
\text { sudah } \\
\text { terpakai" }\end{array}$ & \\
\hline Load & Buka & Menampi & Menampi & Valid \\
\hline
\end{tabular}




\begin{tabular}{|c|c|c|c|c|}
\hline $\begin{array}{l}\text { Fungsi } \\
\text { yang } \\
\text { diuji }\end{array}$ & Kondisi & $\begin{array}{c}\text { Output } \\
\text { yang } \\
\text { diharap } \\
\text { kan }\end{array}$ & $\begin{array}{c}\text { Output } \\
\text { yang } \\
\text { dihasil } \\
\text { kan }\end{array}$ & Status \\
\hline Informasi & $\begin{array}{l}\text { halaman } \\
\text { informasi }\end{array}$ & $\begin{array}{l}\text { lkan } \\
\text { informasi } \\
\text { jadwal } \\
\text { ibadah, } \\
\text { lomba, } \\
\text { dan } \\
\text { seminar }\end{array}$ & $\begin{array}{l}\text { lkan } \\
\text { informasi } \\
\text { jadwal } \\
\text { ibadah, } \\
\text { lomba, } \\
\text { dan } \\
\text { seminar }\end{array}$ & \\
\hline $\begin{array}{l}\text { Load } \\
\text { Registras } \\
\text { i Ibadah }\end{array}$ & $\begin{array}{l}\text { Buka } \\
\text { halaman } \\
\text { registrasi } \\
\text { ibadah }\end{array}$ & $\begin{array}{l}\text { Menampi } \\
\text { lkan } \\
\text { halaman } \\
\text { yang } \\
\text { berisi } \\
\text { peraturan } \\
\text { mengikut } \\
\text { i ibadah, } \\
\text { pilih } \\
\text { ibadah } \\
\text { dan isi } \\
\text { form } \\
\text { registrasi } \\
\text { ibadah }\end{array}$ & $\begin{array}{l}\text { Menampi } \\
\text { lkan } \\
\text { halaman } \\
\text { yang } \\
\text { berisi } \\
\text { peraturan } \\
\text { mengikut } \\
\text { i ibadah, } \\
\text { pilih } \\
\text { ibadah } \\
\text { dan isi } \\
\text { form } \\
\text { registrasi } \\
\text { ibadah }\end{array}$ & Valid \\
\hline $\begin{array}{l}\text { Load } Q R \\
\text { Code }\end{array}$ & $\begin{array}{l}\text { Buka } \\
\text { halaman } \\
\text { QR Code }\end{array}$ & $\begin{array}{l}\text { Menampi } \\
\text { lkan data } \\
\text { registrasi } \\
\text { ibadah } \\
\text { dan } Q R \\
\text { Code } \\
\text { milik } \\
\text { pengguna } \\
\text { akun }\end{array}$ & $\begin{array}{l}\text { Menampi } \\
\text { lkan data } \\
\text { registrasi } \\
\text { ibadah } \\
\text { dan } Q R \\
\text { Code } \\
\text { milik } \\
\text { pengguna } \\
\text { akun }\end{array}$ & Valid \\
\hline $\begin{array}{l}\text { Load } \\
\text { Kontak }\end{array}$ & $\begin{array}{l}\text { Buka } \\
\text { halaman } \\
\text { Kontak }\end{array}$ & $\begin{array}{l}\text { Menampi } \\
\text { lkan } \\
\text { kontak } \\
\text { dan } \\
\text { media } \\
\text { sosial } \\
\text { Mejelis } \\
\text { GKE } \\
\text { Rajawali } \\
\text { Gereja } \\
\text { Asi }\end{array}$ & $\begin{array}{l}\text { Menampi } \\
\text { lkan } \\
\text { kontak } \\
\text { dan } \\
\text { media } \\
\text { sosial } \\
\text { Mejelis } \\
\text { GKE } \\
\text { Rajawali } \\
\text { Gereja } \\
\text { Asi }\end{array}$ & Valid \\
\hline
\end{tabular}

2. Pengujian teknik beta dengan metode kuantitatif

Peneliti akan meminta sample user untuk mengisi kuesioner sebagai pengujian beta dalam tahap ini. Peneliti akan memilih secara acak 30 responden sebagai sample user. Responden dalam tahap beta tester ini adalah jemaat Gereja Asi Palangka Raya dari kalangan remaja sampai orang tua.

\begin{tabular}{|l|l|c|c|c|c|}
\hline No & Pertanyaan & STS & TS & S & SS \\
\hline 1. & $\begin{array}{l}\text { Pengguna dapat } \\
\text { dengan mudah } \\
\text { mengoperasikan } \\
\text { aplikasi ini } \\
\text { (User Friendly) }\end{array}$ & 0 & 0 & 13 & 17 \\
\hline 2. & $\begin{array}{l}\text { Interaksi dalam } \\
\text { aplikasi jelas } \\
\text { dan dapat } \\
\text { dimengerti }\end{array}$ & 0 & 0 & 12 & 18 \\
\hline 3. & $\begin{array}{l}\text { Aplikasi } \\
\text { memiliki }\end{array}$ & 0 & 0 & 18 & 12 \\
\hline
\end{tabular}

\begin{tabular}{|c|c|c|c|c|c|}
\hline No & Pertanyaan & STS & TS & $\mathbf{S}$ & SS \\
\hline & $\begin{array}{l}\text { tampilan yang } \\
\text { menarik }\end{array}$ & & & & \\
\hline 4. & $\begin{array}{l}\text { Pengguna dapat } \\
\text { dengan mudah } \\
\text { menemukan } \\
\text { informasi } \\
\text { terkait gereja }\end{array}$ & 0 & 0 & 11 & 19 \\
\hline 5. & $\begin{array}{l}\text { Penyajian } \\
\text { informasi dalam } \\
\text { aplikasi } \\
\text { memenuhi } \\
\text { kebutuhan } \\
\text { pengguna }\end{array}$ & 0 & 0 & 14 & 16 \\
\hline 6. & $\begin{array}{l}\text { Teks dalam } \\
\text { aplikasi dapat } \\
\text { dibaca dengan } \\
\text { jelas }\end{array}$ & 0 & 0 & 9 & 21 \\
\hline 7. & $\begin{array}{l}\text { Komponen } \\
\text { yang tampil } \\
\text { pada aplikasi } \\
\text { sesuai dengan } \\
\text { kebutuhan } \\
\text { pengguna }\end{array}$ & 0 & 0 & 11 & 19 \\
\hline 8. & $\begin{array}{l}\text { Pengguna dapat } \\
\text { dengan mudah } \\
\text { melakukan } \\
\text { registrasi } \\
\text { ibadah secara } \\
\text { online }\end{array}$ & 0 & 0 & 11 & 19 \\
\hline 9. & $\begin{array}{l}\text { Tidak ada } \\
\text { gangguan dan } \\
\text { error dalam } \\
\text { melakukan } \\
\text { registrasu } \\
\text { ibadah } \\
\end{array}$ & 0 & 0 & 12 & 18 \\
\hline 10 . & $\begin{array}{l}\text { Pengguna dapat } \\
\text { melakukan } \\
\text { pengunduhan } \\
Q R \text { Code }\end{array}$ & 0 & 0 & 11 & 19 \\
\hline 11. & $\begin{array}{l}\text { Aplikasi sangat } \\
\text { berguna bagi } \\
\text { rumah ibadah } \\
\text { pada masa } \\
\text { Pandemi Covid- } \\
19\end{array}$ & 0 & 0 & 6 & 24 \\
\hline
\end{tabular}

Kuesioner yang telah diisi oleh responden akan dihitung presentase jawabannya sehingga semua jawaban dapat diperoleh untuk dianalisis. Terdapat 56.67 persen responden yang memilih sangat setuju pada hasil analisis data untuk pertanyaan pertama. Sedangkan untuk yang menjawab setuju terdapat 43.33 persen. Sehingga pengguna dapat dengan mudah menggunakan atau mengoperasikan aplikasi ini (User Friendly).

Hasil analisis data untuk pertanyaan kedua menunjukan bahwa sangat setuju dipilih oleh 60 persen responden. Sedangkan pilihan setuju dipilih oleh 40 persen responden. Sehingga pengguna dapat 
mengerti dan berinteraksi dalam aplikasi tanpa ada kendala.

Terdapat $60 \%$ responden menjawab setuju dan $40 \%$ responden menjawab sangat setuju berdasarkan hasil analisis data untuk pertanyaan ketiga. Jadi dapat disimpulkan bahwa aplikasi ini memiliki tampilan yang menarik.

Responden yang memilih sangat setuju terdapat 63.33 persen dan yang memilih setuju terdapat 36.67 persen berdasarkan hasil analisis data pada pertanyaan keempat. Sehingga pengguna tidak mengalami kesulitan untuk memperoleh berita dan informasi terbaru tentang Gereja.

Responden yang memutuskan sangat setuju terdapat 53.33 persen dan yang memutuskan setuju sebesar 46.67 persen berdasarkan hasil analisis data pada pertanyaan kelima. Sehingga pengguna dapat memenuhi kebutuhannya dalam penyajian informasi yang terdapat dalam aplikasi.

Responden yang memutuskan sangat setuju terdapat 70 persen dan yang memutuskan setuju sebesar 30 persen berdasarkan hasil analisis data pada pertanyaan keenam. Sehingga pengguna dapat membaca dengan jelas teks yang terdapat dalam aplikasi.

Responden yang memutuskan sangat setuju terdapat 63.33 persen dan yang memutuskan setuju sebesar 36.67 persen berdasarkan hasil analisis data pada pertanyaan ketujuh. Sehingga kebutuhan pengguna dapat ditampilkan dengan sesuai pada fitur atau komponen aplikasi.

Responden yang memutuskan sangat setuju terdapat 63.33 persen dan yang memutuskan setuju sebesar 36.67 persen berdasarkan hasil analisis data pada pertanyaan kedelapan. Sehingga registrasi beribadah secara daring dapat dengan mudah dilakukan pengguna.

Responden yang memutuskan sangat setuju terdapat 60 persen dan yang memutuskan setuju sebesar 40 persen berdasarkan hasil analisis data pada pertanyaan kesembilan. Sehingga pengguna tidak menemui error atau gangguan saat mendaftaran diri untuk beribadah dalam aplikasi ini.

Responden yang memutuskan sangat setuju terdapat 63.33 persen dan yang memutuskan setuju sebesar 36.67 persen berdasarkan hasil analisis data pada pertanyaan kesepuluh. Sehingga $Q R$ Code dapat diunduh oleh pengguna dengan lancar.

Responden yang memutuskan sangat setuju terdapat 80 persen dan yang memutuskan setuju sebesar 20 persen berdasarkan hasil analisis data pada pertanyaan kesebelas. Sehingga saat pandemi Covid19, aplikasi ini sangat bermanfaat bagi jemaat Gereja.

\section{KESIMPULAN}

Berdasarkan implementasi dan pengujian yang dilakukan maka dapat disimpulkan bahwa perancangan sistem informasi registrasi ibadah online berbasis $Q R$ Code menggunakan framework laravel yang dikembangkan dengan menggunakan database bahasa program MySQL dan PHP. QR Code dapat digunakan sebagai alat digital yang dapat mempermudah dan mempersepat proses registrasi ibadah, dan dengan adanya aplikasi ini dapat memudahkan pihak gereja menginformasikan peraturan protokol kesehatan dan membatasi kapasitas jemaat yang akan beribadah secara offline di gereja. Pada penelitian ini diharapkan untuk kedepannya pengembang tidak hanya berfokus pada registrasi ibadah saja, namun bisa dikembangkan ke dalam skema yang lebih universal seperti penambahan halaman liturgi, daftar petugas dan penugasannya, penyajian renungan, notifikasi bagi jemaat yang bertugas, dan pencatatan pokok doa jika ada anggota jemaat yang ingin didoakan.

\section{DAFTAR PUSTAKA}

[1] Dispernaker, "Peran Teknologi di Tengah Pandemi Covid - 19," http://dispernaker.salatiga.go.id/, 2020. [Online]. Available: http://dispernaker.salatiga.go.id/peranteknologi-di-tengah-pandemi-covid-19/.

[2] Kompas.com, "New Normal', Rumah Ibadah Akan Dibuka Bertahap," Kompas.com, 2020. [Online]. Available: https://nasional.kompas.com/read/2020/05/27/ 13540321/new-normal-rumah-ibadah-akandibuka-bertahap.

[3] D. Nurita, "Aturan Baru: Anak-anak dan Lansia Dilarang ke Rumah Ibadah," tempo.com, 2020. [Online]. Available: https://nasional.tempo.co/read/1347953/aturan -baru-anak-anak-dan-lansia-dilarang-kerumah-ibadah/full\&view=ok.

[4] "Tempat Ibadah Mulai Aktif Tetapi Harus Laksanakan Protokol Kesehatan," mediacenter.palangkaraya, 2020. [Online]. Available:

mediacenter.palangkaraya.go.id/tempatibadah-mulai-aktif-tetapi-harus-laksanakanprotokol-kesehatan/.

[5] I. K. Aditya, H. Putra, D. Pramana, N. Luh, and P. Srinadi, "Sistem Manajemen Arsip Menggunakan Framework Laravel dan Vue . Js ( Studi Kasus: BPKAD Provinsi Bali )," Sist. dan Inform., vol. 13, no. 2, pp. 97-104, 2019.

[6] Z. Munawar, "APLIKASI REGISTRASI SEMINAR BERBASIS WEB MENGGUNAKAN $Q R \quad C O D E$ PADA UNIVERSITAS XYZ,” J. Teknol. Inf. Dan Komun., vol. 5, no. 2, pp. 68-77, 2018.

[7] Aminudin, "Cara Efektif Belajar Framework Laravel,” Ilmu Teknol. Inf., pp. 1-28, 2015.

[8] Q. Aini, U. Rahardja, and A. Fatillah, "Penerapan Qrcode Sebagai Media Pelayanan 
Untuk Absensi Pada Website Berbasis Php Native," Sisfotenika, vol. 8, no. 1, p. 47, 2018, doi: 10.30700/jst.v8i1.151.

[9] Hanafi, "Konsep Penelitian R \& D Dalam Bidang Pendidikan," Saintifika Islam. J. Kaji. Keislam., vol. 4, no. 2, pp. 129-150, 2017.

[10] S. Pastima and A. Kasnady, "Analisis Model View Controller (MVC) Pada Bahasa Php," J. ISD, vol. 2, no. 2, pp. 56-66, 2016.

[11] Y. Wiharto, "Perancangan Sistem Perpustakaan Menggunakan Model View Controller (Mvc) Dengan Metode Object Modelling Technique (Omt) Pada Sekolah Menengah Pertama Negeri 44 Palembang," J. Tek. Inform., vol. 10, no. 2, pp. 147-158, 2018, doi: 10.15408/jti.v10i2.6993.

[12] J. Rouillard, "Contextual $Q R$ Codes. Proceedings of ICCGI 2008:," 3rd Int. multiconference Comput. Glob. Inf. Technol., 2008.

[13] A. Rahmawati and A. Rahman, "Sistem Pengamanan Keaslian Ijasah Menggunakan QR-Code dan Algoritma," Seminar, vol. 1, no. 2, pp. 105-112, 2011.

[14] M. K. Yuli Syafitri, "ANALISA DAN PERANCANGAN BERBASIS UML PADA SISTEM INFORMASI SIMPAN PINJAM KOPERASI SWAMITRA BANDAR LAMPUNG," pp. 22-31. 